\title{
Peterlin, D 1995 - Paul's letter to the Philippians in the light of Disunity in the Church (Supplements to Novum Testamentum LXXIX.)
}

Leiden: Brill. 270 Pages. Price: Unknown.

\section{Reviewer: Dr P B Boshoff}

Epaphroditus was an influential and well-to-do person who played a leading role in the Philippian church (204). He undertook a visit to Paul in prison in order to hand over the congregation's modest financial contribution on the occasion (180-181, 184). He covered the costs of his journey and lodgings himself, and undertook to see to Paul's further needs. Epaphroditus was Paul's leitourgos in terms of providing money. When Epaphroditus fell ill in Rome he feared that the small number of Christians in Philippi may interpret his illness as affirmation of the unsuccessful nature of his mission. Paul's imprisonment had already evoked serious doubts, as the Philippians battled to reconcile themselves with his situation. How could the Lord allow his legate to be subjected to such an ordeal and his work to be subsequently handicapped. Coming from a context of paganism they anticipated Christian life to be much more glamorous, and battled to reconcile suffering with it. 'Was he doing his best to proclaim the gospel? Wasn't he compromising Christ by being thrown into jail? Isn't the Christian life all about victorious living?' (48). Suffering became a burning question as they - as congregation - were increasingly socially ostracized $(50-51,219)$.

Peterlin proposes that Paul doesn't react so much to dissenting theological viewpoints. He does not regard theological opponents as the real danger, but rather a potential threat from outside the congregation. The letter is not intended for those representing the threat. They don't read the letter themselves, but are indicated by Paul as a bad example, not to be followed. He fears that certain tendencies within 
the congregation could cause the 'opponents' to get an active influence over the Philippians. Peterlin admits that there are perfectionistic tendencies among some Philippian Christians, but this is not a detailed theological position against which Paul would have reacted $(99,219)$.

Peterlin comes to the conclusion that divisional tension is behind the words of the Philippian letter. Paul's anxiety about the unity becomes obvious in the opening remark when he addresses 'all'. He pinpoints the problem in 4:2 when he admonishes Euodia and Syntyche, the two female deacons, to be likeminded. They were among the earliest converts and leaders of house-congregations in Philippi. 'As leaders and patrons they would easily muster the support of their subordinates and sway them in their direction resulting in the estrangement of whole house-congregations' (127).

Paul doesn't choose sides between the groups, he just wants to win over those who are against him (227). The discordance is about Paul himself (75), to such an extend that some withhold financial support from him (203). The struggle that ensues causes the congregation to split leadership around Euodia and Syntyche. One group still supports Paul, while the other feels that he, because of his imprisonment, no longer deserves their co-operation (221). An unedifying struggle for power develops.

Paul, having been informed by Epaphroditus, writes his letter to the Philippians against this background. Keeping the discord in mind right through, his aim is to quide the Philippians toward reconciliation.

This book, in attempting to provide answers to historic questions, offers good reading to the historic-critical reader of the New Testament. However, I sincerely doubt whether the view that the Philippian letter consists of one letter only, will really convince. The understating of any profound theological motive in Paul's writing will also remain a problem. Interesting though, is the light that is shed on Epaphroditus, and the nature of his involvement in arguments. Overall impression: A book to be read. 